\title{
Assessing the impact of a mushroom- derived food ingredient on vitamin $D$ levels in healthy volunteers
}

\author{
Jorge Marques Pinto ${ }^{1 *}$, Viviane Merzbach¹, Ashley G. B. Willmott', Jose Antonio ${ }^{2}$ and Justin Roberts ${ }^{1 *}$ (D)
}

\begin{abstract}
Background: Prevalence of vitamin D insufficiency/deficiency has been noted in athletic populations, although less is known about recreationally active individuals. Biofortification of natural food sources (e.g. UV radiated mushrooms) may support vitamin D status and is therefore of current scientific and commercial interest. The aim of this study was to assess the impact of a mushroom-derived food ingredient on vitamin D status in recreationally active, healthy volunteers.
\end{abstract}

Methods: Twenty-eight participants were randomly assigned to either: $25 \mu \mathrm{g}$ (1000 IU) encapsulated natural mushroom-derived vitamin $D_{2}$; matched-dose encapsulated vitamin $D_{3}$ or placebo (PL) for 12 weeks. Venous blood samples were collected at baseline, week 6 and 12 for analysis of serum $25(\mathrm{OH}) \mathrm{D}_{2}$ and $25(\mathrm{OH}) \mathrm{D}_{3}$ using liquid chromatography mass spectrometry. Habitual dietary intake and activity were monitored across the intervention.

Results: Vitamin D status $\left(25(\mathrm{OH}) \mathrm{D}_{\text {TOTAL }}\right)$ was significantly increased with vitamin $\mathrm{D}_{3}$ supplementation from $46.1 \pm$ $5.3 \mathrm{nmol} \cdot \mathrm{L}^{-1}$ to $88.0 \pm 8.6 \mathrm{nmol} \cdot \mathrm{L}^{-1}(p<0.0001)$ across the intervention, coupled with an expected rise in $25(\mathrm{OH}) \mathrm{D}_{3}$ concentrations from $38.8 \pm 5.2 \mathrm{nmol} \cdot \mathrm{L}^{-1}$ to $82.0 \pm 7.9 \mathrm{nmol} \cdot \mathrm{L}^{-1}(p<0.0001)$. In contrast, $\mathrm{D}_{2}$ supplementation increased $25(\mathrm{OH}) \mathrm{D}_{2}$ by $+347 \%\left(7.0 \pm 1.1 \mathrm{nmol} \cdot \mathrm{L}^{-1}\right.$ to $\left.31.4 \pm 2.1 \mathrm{nmol} \cdot \mathrm{L}^{-1}, p<0.0001\right)$, but resulted in $\mathrm{a}-42 \%$ reduction in $25(\mathrm{OH}) \mathrm{D}_{3}$ by week $6(p=0.001)$. A net $+14 \%$ increase in $25(\mathrm{OH}) \mathrm{D}_{\text {TOTAL }}$ was established with $\mathrm{D}_{2}$ supplementation by week $12(p>0.05)$, which was not statistically different to $D_{3}$. Vitamin $D$ status was maintained with $\mathrm{PL}$, following an initial $-15 \%$ reduction by week 6 ( $p \leq 0.046$ compared to both supplement groups).

Conclusions: The use of a UV radiated mushroom food ingredient was effective in maintaining 25(OH) $\mathrm{D}_{\text {TOTAL }}$ in healthy, recreationally active volunteers. This may offer an adjunct strategy in supporting vitamin D intake. However, consistent with the literature, the use of vitamin $D_{3}$ supplementation likely offers benefits when acute elevation in vitamin D status is warranted.

Keywords: Vitamin D status, Vitamin $D_{2}$, Recreationally active, UV radiated mushrooms

\footnotetext{
* Correspondence: jorge.madeira@student.aru.ac.uk; justin.roberts@aru.ac.uk

${ }^{1}$ Cambridge Centre for Sport and Exercise Sciences, School of Psychology

and Sport Science, Anglia Ruskin University, Compass House, East Road,

Cambridge CB1 1PT, UK

Full list of author information is available at the end of the article
}

(C) The Author(s). 2020 Open Access This article is licensed under a Creative Commons Attribution 4.0 International License, which permits use, sharing, adaptation, distribution and reproduction in any medium or format, as long as you give appropriate credit to the original author(s) and the source, provide a link to the Creative Commons licence, and indicate if changes were made. The images or other third party material in this article are included in the article's Creative Commons licence, unless indicated otherwise in a credit line to the material. If material is not included in the article's Creative Commons licence and your intended use is not permitted by statutory regulation or exceeds the permitted use, you will need to obtain permission directly from the copyright holder. To view a copy of this licence, visit http://creativecommons.org/licenses/by/4.0/ The Creative Commons Public Domain Dedication waiver (http://creativecommons.org/publicdomain/zero/1.0/) applies to the data made available in this article, unless otherwise stated in a credit line to the data. 


\section{Introduction}

Vitamin D in its two most common forms, ergocalciferol (vitamin $\mathrm{D}_{2}$ ) and cholecalciferol (vitamin $\mathrm{D}_{3}$ ), is a pro-hormone [1] involved in numerous physiological processes including: bone mineralisation, calcium and phosphorus homeostasis, neuromuscular function, cell growth regulation and immune modulation [2-5]. Both forms of vitamin $\mathrm{D}$ undertake the same enzymatic hydroxylation reactions to become biologically active. The first reaction takes place in the liver catalysed by the action of 25-hydroxylase, which converts vitamin $\mathrm{D}_{2}$ or $\mathrm{D}_{3}$ to 25 -hydroxyvitamin $\mathrm{D}_{2}\left(25(\mathrm{OH}) \mathrm{D}_{2}\right)$ and 25 hydroxyvitamin $\mathrm{D}_{3}\left(25(\mathrm{OH}) \mathrm{D}_{3}\right)$, respectively. Following transport to the kidneys by vitamin $\mathrm{D}$-binding proteins (DBP) and further catalysation by $1-\alpha$-hydroxylase, both forms are converted into active 1,25-dihydroxyvitamin $\mathrm{D}\left(1,25(\mathrm{OH})_{2} \mathrm{D}\right)$ [4]. It has been shown that both 1 , $25(\mathrm{OH})_{2} \mathrm{D}_{2}$ and $1,25(\mathrm{OH})_{2} \mathrm{D}_{3}$ have similar affinities for the vitamin $\mathrm{D}$ receptor (VDR) $[6,7]$, and comparably influence biological activity in vivo [8].

Modulation of vitamin D concentrations occurs through endogenous synthesis following ultra-violet (UV) sunlight radiation exposure (wavelengths $290-315 \mathrm{~nm}$ ) and resulting conversion of 7-dehydrocholesterol to vitamin $\mathrm{D}_{3}$ [4]. In the Northern hemisphere (latitudes of $>30^{\circ}$ north), or where exposure to such UV radiation is limited (particularly across autumn/winter periods), vitamin D insufficiency $\left(25(\mathrm{OH}) \mathrm{D}_{\text {TOTAL }}\right.$ level $\left.<50 \mathrm{nmol} \cdot \mathrm{L}^{-1}\right)$ [9] can have health implications which may go unrecognised [10]. Indeed, a recent UK nutrition survey reported vitamin D deficiency $\left(<25 \mathrm{nmol} \cdot \mathrm{L}^{-1}\right)$ in $15 \%$ of women and $19 \%$ of men aged 19-64 years [11]; with other authors highlighting that only 18 and $24.1 \%$ of women and men in the UK, respectively, were classed as having 'adequate' vitamin $\mathrm{D}$ status [12, 13]. Worldwide it is estimated that approximately 1 billion people are considered to have vitamin $\mathrm{D}$ insufficiency or deficiency $\left(25(\mathrm{OH}) \mathrm{D}_{\text {TOTAL }}<50 \mathrm{nmol} \cdot \mathrm{L}^{-1}\right)$ [2]. Previous research has also demonstrated that trained athletes may be at risk of vitamin D insufficiency or deficiency $[14,15]$, which can impact on training adaptations, exercise recovery and injury prevalence [16, 17], and should be regularly monitored. However, less is known about recreationally active individuals who may also be at a similar risk of lowered vitamin D status.

Vitamin D status can also be influenced by dietary intake, with animal sources (e.g. cod liver oil, salmon, cheese, red meats, milk, eggs) [18] and fortified foods providing exogenous vitamin $\mathrm{D}_{3}$; and plant- or fungi-based foods (e.g. phytoplankton, mushrooms, yeast) providing small quantities of vitamin $\mathrm{D}_{2}$. According to the Scientific Advisory Committee on Nutrition (UK) [19], the average daily intake necessary to sustain $25(\mathrm{OH}) \mathrm{D}_{\text {TOTAL }}$ levels above 25 $\mathrm{nmol} \cdot \mathrm{L}^{-1}$ during the winter season in the UK is $\sim 10 \mu \mathrm{g} \cdot \mathrm{d}^{-1}$ $\left(400 \mathrm{IU} \cdot \mathrm{d}^{-1}\right)$, with average dietary intakes reportedly lower than this [11]. As such, food-based solutions and supplementation to increase vitamin $\mathrm{D}$ intake in the population have been strongly emphasised [20].

Whilst fortification offers one potential solution, the lack of diversity of food items has been suggested as a reason for relatively low overall contribution to vitamin $\mathrm{D}$ intake [11]. Supplementation with vitamin $\mathrm{D}_{3}$ offers another effective strategy to increase dietary intake and raise physiological concentrations of vitamin D [21]. However, costly synthetic production and the sources used (e.g. lanolin and fish oil) [22, 23] potentially make these strategies impractical or unsuitable for specific dietary regimes (e.g. vegan/vegetarian) [12]. Biofortification offers a new approach to increasing the nutritional content of a wide range of foods, supporting dietary requirement inclusivity $[4,24]$. As example, a new method of UV radiation of edible mushrooms [24] has the potential to produce more bioavailable vitamin $\mathrm{D}_{2}$ at relatively low cost [20, 23, 25-27], with specific species (i.e. Agaricus bisporus, Lentinula edodes and Pleurotus ostreatus) achieving up to $40 \mu \mathrm{g}$ of ergocalciferol per $100 \mathrm{~g}$ of dried mushroom mass [10, 23].

It has been suggested that the bioefficacy between vitamin $D_{2}$ and $D_{3}$ differs [28], with intervention studies highlighting a superior effect of vitamin $\mathrm{D}_{3}$ in raising $25(\mathrm{OH}) \mathrm{D}_{\text {TOTAL }}$ levels [29-42]. However, other studies contest there is less difference in the bioefficacy of vitamin $D_{2}$ compared to $D_{3}$, especially when supplementation administered as daily dosages is considered [21, 29, $32,35,38,40,43-45]$. Few studies have investigated the impact of vitamin $D_{2}$ supplementation from natural sources (e.g. UV radiated mushrooms) on vitamin D status [24], and the heterogeneity of those studies (e.g. non-placebo control, variable dosages, population type) makes it difficult to draw meaningful conclusions on whether vitamin $D_{2}$ derived from mushrooms was effective. As such, the aim of this study was to conduct an independent assessment into the impact of a commercially utilised mushroom-derived food ingredient on vitamin D status in recreationally active healthy volunteers, compared with both vitamin $\mathrm{D}_{3}$ and placebo-control supplementation. It was hypothesised that natural vitamin $\mathrm{D}_{2}$ would provide an adjunct strategy to support vitamin D status compared with vitamin $\mathrm{D}_{3}$.

\section{Methods \\ Study design}

This study employed a randomised, double-blinded, placebo-controlled design over a 12-week period. The study was conducted in accordance with the Declaration of Helsinki (2013), with ethical approval from the Faculty of Science and Technology Ethics Committee, Anglia Ruskin University (Project Number: FST/FREP/18773). 


\section{Participants}

An a priori power calculation based on previous data [36] utilising $\alpha=0.05$ and $1-\beta=0.8$, estimated a sample size of 27 participants. Following a study briefing, all participants provided written informed consent prior to study inclusion. Participants were required to be healthy volunteers, satisfactorily complete a health screen questionnaire, and be prepared to comply with study requirements. Participants with a known history of cardio-metabolic disorders, blood related disorders, and recent viral infections were not eligible for study inclusion. Likewise, anyone reporting use of prescribed medication or supplementation (e.g. current vitamin D use) which could conflict with the study parameters, as well as those with known adverse or allergic reactions to dietary intake of mushrooms were not included in the study. Based on the nature of the supplementation, vegans were also not eligible for study inclusion. Any participants with high starting vitamin D levels (> 150 $\mathrm{nmol} \cdot \mathrm{L}^{-1}$ ) were not included in the study.

Thirty-three participants (20 males, 13 females) were initially recruited. One participant was subsequently withdrawn due to medication use conflicting with study parameters; three participants were withdrawn due to non-compliance with food/activity diaries, and data for one participant was excluded due to high initial starting vitamin $\mathrm{D}$ concentration based on recent use of vitamin $\mathrm{D}_{3}$ supplementation. Twenty-eight participants (16 males, 12 females) were therefore included in the final analysis having completed all aspects of the study. Participant characteristics are shown in Table 1.

\section{Procedures}

All testing procedures took place in the Cambridge Centre for Sport and Exercise Sciences laboratories at Anglia Ruskin University, under controlled conditions between January-April 2019. Participants were required to attend the laboratory, having rested in the 24-h prior and having had their last meal $\sim 12$-h before the appointment, at baseline, week 6 and week 12. Upon arrival, each participant's height was measured using a stadiometer (Seca CE123, Hamburg, Germany), and body mass and body fat percentage were assessed through the use of bioelectrical impedance analysis scales (Tanita BC420SMA, Amsterdam, The Netherlands).

\section{Blood sampling and analysis}

Once anthropometric measurements were recorded, participants rested in a semi-prone position for 5-min prior to a venous whole blood sample collection by a qualified phlebotomist into duplicate $4 \mathrm{~mL}$ K3EDTA vacutainers (Greiner Bio-One $\mathrm{GmbH}$, Kremsmunster, Austria). Samples were centrifuged for 10-min at 2000 rpm, with aliquoted serum pipetted into sterile, nonpyrogenic, polypropylene cryovials (Fisherbrand, Fisher Scientific, Loughborough, UK) and frozen at $-20^{\circ} \mathrm{C}$ for later assessment of serum $25(\mathrm{OH}) \mathrm{D}_{2}$ and $25(\mathrm{OH}) \mathrm{D}_{3}$. All samples were analysed in conjunction with the Core Biochemical Analysis Laboratory (CBAL), Addenbrookes Hospital, Cambridge. Liquid chromatography-mass spectrometry (AB Sciex Mass spectrometer [API5500]) was utilised for the quantitative analysis of $25(\mathrm{OH}) \mathrm{D}_{2}$ and $25(\mathrm{OH}) \mathrm{D}_{3}$. The lower quantitation limit for the assay was 5 nmol. $\mathrm{L}^{-1}$ for both $25(\mathrm{OH}) \mathrm{D}_{2}$ and $25(\mathrm{OH}) \mathrm{D}_{3}$, and the upper limit was $130 \mathrm{nmol} \cdot \mathrm{L}^{-1}$ and $170 \mathrm{nmol} \cdot \mathrm{L}^{-1}$ for $25(\mathrm{OH}) \mathrm{D}_{2}$ and $25(\mathrm{OH}) \mathrm{D}_{3}$, respectively [46].

\section{Supplement interventions}

Following baseline assessment, participants were category-coded according to initial vitamin $\mathrm{D}$ levels (e.g. deficient $<25 \mathrm{nmol} \cdot \mathrm{L}^{-1}$, insufficient $25-49 \mathrm{nmol} \cdot \mathrm{L}^{-1}$, inadequate $50-74 \mathrm{nmol} \cdot \mathrm{L}^{-1}$, adequate $>75 \mathrm{nmol} \cdot \mathrm{L}^{-1}$ ) [47], and then within category randomly assigned to intervention condition to minimise testing bias. As such, participants were allocated in a double-blinded manner to one of the three intervention groups. At baseline and week 6 visits, participants were provided (according to their initial intervention group allocation) with a 6-week supply of either: encapsulated vitamin $\mathrm{D}_{2}$ (VitaShroomD, Cambridge Commodities Ltd. [CCL]), containing $25 \mu \mathrm{g}$ (1000 $\mathrm{IU})$ of natural mushroom-derived vitamin $\mathrm{D}_{2}$ powder; encapsulated vitamin $\mathrm{D}_{3}$ (Cholecalciferol, $\mathrm{CCL}$ ), containing $25 \mu \mathrm{g}(1000 \mathrm{IU})$ of vitamin $\mathrm{D}_{3}$, or placebo (PL, ProEarth Organic Sunflower Protein 45\%, CCL). All products were manufactured and pre-capsulated (hypromellose vegetable capsules) to clinical standards via CCL and evaluated by the European Food Safety Authority. All supplements were provided in standardised opaque sealed pots for hygiene and double-blinding purposes and administered independently of the manufacturing

Table 1 Characteristics of participants at baseline by intervention group

\begin{tabular}{|c|c|c|c|}
\hline & Vitamin $D_{2}(n=10,7 \mathrm{M}, 3 \mathrm{~F})$ & Vitamin $D_{3}(n=10,5 \mathrm{M}, 5 \mathrm{~F})$ & $\mathrm{PL}(n=8,4 \mathrm{M}, 4 \mathrm{~F})$ \\
\hline Age (yrs) & $36 \pm 3$ & $38 \pm 4$ & $30 \pm 3$ \\
\hline Height (cm) & $174.4 \pm 3.1$ & $171.8 \pm 2.1$ & $173.2 \pm 4.3$ \\
\hline Body mass (kg) & $74.0 \pm 3.7$ & $78.2 \pm 5.0$ & $77.5 \pm 6.7$ \\
\hline Body fat (\%) & $22.2 \pm 2.4$ & $27.9 \pm 3.6$ & $25.2 \pm 4.2$ \\
\hline Body mass index $\left(\mathrm{kg} \cdot \mathrm{m}^{2}\right)$ & $24.4 \pm 1.3$ & $26.6 \pm 1.8$ & $25.4 \pm 1.2$ \\
\hline
\end{tabular}

$M$ male, $F$ female, $P L$ placebo. No differences reported between groups for any variable. Data are presented as mean \pm standard error $(M \pm S E)$ 
company. As a means to monitor supplement adherence, participants were required to complete a daily compliance record throughout the intervention. As a crosscheck measure, participants returned pots at follow-up visits, and excess capsules were counted.

\section{Dietary intake and activity monitoring}

All participants were required to complete food and activity diaries to assess individual consistency across the intervention period. At the baseline visit, participants were provided with an individual MyFitnessPal account to record their dietary intake and were instructed to maintain their physical activity levels and dietary habits throughout the intervention period. For exercise activity across the intervention, participants recorded exercise type, duration, and overall session rating of perceived exertion (sRPE), with estimated training load, monotony, and strain determined as previously described [48, 49]. Food diaries were collated by participants in the first 7days of supplementation and the 7-days leading into the week- 6 and week-12 laboratory visits, respectively. Participants were provided with example diaries and individually instructed in diary completion, with emphasis on meal breakdown, portion size/weight and weighing procedure. Dietary analyses were undertaken by the same researcher for standardisation by transferring data for three weekdays and one weekend day from the individual MyFitnessPal accounts to the Nutritics Professional Dietary Analysis software (Nutritics Limited, Dublin), utilising the Composition of Foods Integrated Dataset (COFIDS) incorporating McCance and Widdowson (7th Edition) database.

\section{Statistical analysis}

Statistical analyses were performed using SPSS (IBM, Version 24.0). Normality of data was verified by the Shapiro-Wilk test. Outliers were identified by inspection of box plots > 1.5 IQR in SPSS. Baseline measures were assessed using between groups ANOVAs. Repeated measures ANOVAs were used to compare group $\mathrm{x}$ time effects with Bonferroni post-hoc assessment where applicable. Where sphericity was violated a Greenhouse-Geisser correction was applied. An alpha level of $p \leq 0.05$ was considered statistically significant for all tests. Data are presented as $\mathrm{M} \pm \mathrm{SE}$.

\section{Results}

\section{Dietary intake, supplement compliance and activity monitoring}

Mean dietary intakes at baseline and across the intervention are shown in Table 2 (absolute) and Table 3 (relative). Energy intake was initially 30\% higher (+534 $\left.\mathrm{kcal} \cdot \mathrm{d}^{-1}\right)$ at baseline for $\mathrm{D}_{2}$ compared to $\mathrm{D}_{3}$ only $(p=$ $0.03)$. This corresponded with a $56 \%$ higher $\left(+96 \mathrm{~g} \cdot \mathrm{d}^{-1}\right)$
Table 2 Dietary intake (total) at baseline, week 6 and 12 by intervention group

\begin{tabular}{|c|c|c|c|}
\hline Variable & Vitamin $D_{2}$ & Vitamin $D_{3}$ & PL \\
\hline \multicolumn{4}{|c|}{ Energy intake $\left(\mathrm{kcal} \cdot \mathrm{d}^{-1}\right)$} \\
\hline Baseline & $2397.9 \pm 136.0^{*}$ & $1844.3 \pm 157.0$ & $1946.4 \pm 128.7$ \\
\hline Week 6 & $2035.6 \pm 132.9$ & $1919.0 \pm 181.2$ & $1984.0 \pm 226.3$ \\
\hline Week 12 & $2123.1 \pm 152.6$ & $1724.2 \pm 185.3$ & $1824.8 \pm 199.5$ \\
\hline \multicolumn{4}{|c|}{ Carbohydrate $\left(g \cdot d^{-1}\right)$} \\
\hline Baseline & $268.3 \pm 29.8^{*}$ & $172.1 \pm 12.7$ & $202.7 \pm 8.6$ \\
\hline Week 6 & $226.2 \pm 20.9$ & $199.4 \pm 26.7$ & $208.0 \pm 18.5$ \\
\hline Week 12 & $222.0 \pm 23.2$ & $180.8 \pm 19.9$ & $195.7 \pm 21.5$ \\
\hline \multicolumn{4}{|l|}{ Fat $\left(g \cdot d^{-1}\right)$} \\
\hline Baseline & $94.9 \pm 4.4$ & $80.2 \pm 8.3$ & $80.1 \pm 7.3$ \\
\hline Week 6 & $80.3 \pm 9.6$ & $76.9 \pm 6.3$ & $83.6 \pm 13.0$ \\
\hline Week 12 & $91.2 \pm 7.3$ & $75.1 \pm 9.5$ & $75.2 \pm 9.4$ \\
\hline \multicolumn{4}{|c|}{$\operatorname{Protein}\left(g \cdot d^{-1}\right)$} \\
\hline Baseline & $107.4 \pm 11.0$ & $88.3 \pm 7.3$ & $102.4 \pm 13.4$ \\
\hline Week 6 & $95.2 \pm 11.9$ & $85.5 \pm 9.1$ & $96.0 \pm 12.7$ \\
\hline Week 12 & $97.9 \pm 13.7$ & $69.8 \pm 6.6$ & $90.4 \pm 14.5$ \\
\hline \multicolumn{4}{|c|}{ Calcium (mg. $\left.d^{-1}\right)$} \\
\hline Baseline & $1024.7 \pm 124.3^{*}$ & $677.4 \pm 50.9$ & $904.4 \pm 83.8$ \\
\hline Week 6 & $927.1 \pm 90.0$ & $693.9 \pm 87.8$ & $776.2 \pm 87.6$ \\
\hline Week 12 & $961.3 \pm 110.2$ & $705.3 \pm 92.2$ & $608.0 \pm 70.8^{\#}$ \\
\hline \multicolumn{4}{|c|}{ Vitamin $D\left(\mu \mathrm{g} \cdot d^{-1}\right)$} \\
\hline Baseline & $4.6 \pm 1.0$ & $2.9 \pm 0.5$ & $2.9 \pm 0.9$ \\
\hline Week 6 & $5.3 \pm 1.3$ & $3.2 \pm 0.9$ & $4.1 \pm 0.7$ \\
\hline Week 12 & $4.4 \pm 1.4$ & $2.6 \pm 0.6$ & $3.9 \pm 0.9$ \\
\hline
\end{tabular}

"denominates significant difference to vitamin $\mathrm{D}_{3}$ at baseline only $(p \leq 0.03)$. " denominates significant difference to both baseline and week 6 within group only $(p \leq 0.03)$

carbohydrate intake for $\mathrm{D}_{2}$ compared with $\mathrm{D}_{3}$ only $(p=0.006)$, and similarly, was reflected in relative intakes at baseline. For main macronutrients, no differences were reported between and within groups at either week 6 or 12, highlighting dietary consistency.

For selected micronutrients, it was noted that absolute calcium intake was $51 \%$ higher $\left(+347.3 \mathrm{mg} \cdot \mathrm{d}^{-1}\right)$ for $\mathrm{D}_{2}$ compared with $\mathrm{D}_{3}$ also at baseline only $(p=0.03)$. A group $\mathrm{x}$ time interaction effect was also found for calcium, with absolute intakes $\left(\mathrm{F}=2.99, p=0.028, \eta \mathrm{p}^{2}=\right.$ 0.20 ) being significantly reduced at week 12 for PL only compared with week $6(p=0.029)$ and baseline $(p=$ $0.001)$. No other differences were reported between conditions for any of the dietary variables, including vitamin D intake. Average supplement compliance was reported at $93.1 \pm 1.5 \%$ (with no differences reported between intervention groups: $95.8 \pm 1.2 \%$ (vitamin $\mathrm{D}_{2}$ ), $91.0 \pm$ $2.2 \%$ (vitamin $\mathrm{D}_{3}$ ) and $93.0 \pm 4.3 \%$ (PL); $p>0.05$ ).

Mean weekly activity monitoring is shown in Table 4. For weekly training load, a significant interaction effect 
Table 3 Dietary intake (relative) at baseline, week 6 and 12 by intervention group

\begin{tabular}{|c|c|c|c|}
\hline Variable & Vitamin $D_{2}$ & Vitamin $D_{3}$ & $\mathrm{PL}$ \\
\hline \multicolumn{4}{|c|}{ Energy intake $\left(\mathrm{kcal} \cdot \mathrm{kg}^{-1} \cdot \mathrm{d}^{-1}\right)$} \\
\hline Baseline & $32.6 \pm 1.2^{*}$ & $24.3 \pm 2.3$ & $26.1 \pm 2.2$ \\
\hline Week 6 & $28.1 \pm 1.9$ & $25.0 \pm 1.8$ & $26.0 \pm 2.3$ \\
\hline Week 12 & $29.3 \pm 2.1$ & $22.8 \pm 2.3$ & $24.2 \pm 1.6$ \\
\hline \multicolumn{4}{|c|}{ Carbohydrate $\left(g \cdot \mathrm{kg}^{-1} \cdot \mathrm{d}^{-1}\right)$} \\
\hline Baseline & $3.6 \pm 0.3^{*}$ & $2.3 \pm 0.2$ & $2.8 \pm 0.4$ \\
\hline Week 6 & $3.1 \pm 0.2$ & $2.6 \pm 0.3$ & $2.8 \pm 0.3$ \\
\hline Week 12 & $3.0 \pm 0.3$ & $2.4 \pm 0.2$ & $2.7 \pm 0.3$ \\
\hline \multicolumn{4}{|c|}{ Fat $\left(g \cdot \mathrm{kg}^{-1} \cdot \mathrm{d}^{-1}\right)$} \\
\hline Baseline & $1.3 \pm 0.1$ & $1.1 \pm 0.1$ & $1.1 \pm 0.1$ \\
\hline Week 6 & $1.1 \pm 0.2$ & $1.0 \pm 0.1$ & $1.1 \pm 0.1$ \\
\hline Week 12 & $1.3 \pm 0.1$ & $1.0 \pm 0.1$ & $1.0 \pm 0.1$ \\
\hline \multicolumn{4}{|c|}{$\operatorname{Protein}\left(g \cdot \mathrm{kg}^{-1} \cdot \mathrm{d}^{-1}\right)$} \\
\hline Baseline & $1.5 \pm 0.1$ & $1.2 \pm 0.1$ & $1.3 \pm 0.1$ \\
\hline Week 6 & $1.3 \pm 0.1$ & $1.1 \pm 0.1$ & $1.3 \pm 0.1$ \\
\hline Week 12 & $1.3 \pm 0.1$ & $0.9 \pm 0.1$ & $1.2 \pm 0.1$ \\
\hline \multicolumn{4}{|c|}{ Calcium (mg $\left.\cdot \mathrm{kg}^{-1} \cdot \mathrm{d}^{-1}\right)$} \\
\hline Baseline & $14.0 \pm 1.6$ & $9.0 \pm 1.0$ & $12.6 \pm 2.0$ \\
\hline Week 6 & $12.7 \pm 1.1$ & $9.5 \pm 1.5$ & $10.8 \pm 1.6$ \\
\hline Week 12 & $13.1 \pm 1.3$ & $9.5 \pm 1.5$ & $8.5 \pm 1.1^{\#}$ \\
\hline \multicolumn{4}{|c|}{ Vitamin D $\left(\mu g \cdot \mathrm{kg}^{-1} \cdot \mathrm{d}^{-1}\right)$} \\
\hline Baseline & $0.06 \pm 0.01$ & $0.04 \pm 0.01$ & $0.04 \pm 0.01$ \\
\hline Week 6 & $0.08 \pm 0.02$ & $0.04 \pm 0.01$ & $0.06 \pm 0.01$ \\
\hline Week 12 & $0.06 \pm 0.02$ & $0.03 \pm 0.01$ & $0.05 \pm 0.01$ \\
\hline
\end{tabular}

Table 4 Mean physical activity load over weeks 0-6 (T1) and 712 (T2) by intervention group

\begin{tabular}{|c|c|c|c|}
\hline Variable & Vitamin $D_{2}$ & Vitamin $D_{3}$ & $\mathrm{PL}$ \\
\hline \multicolumn{4}{|c|}{ Weekly training load (AU) } \\
\hline $\mathrm{T} 1$ & $1538 \pm 321$ & $1413 \pm 627$ & $1954 \pm 307$ \\
\hline $\mathrm{T} 2$ & $1498 \pm 262$ & $1690 \pm 617$ & $1313 \pm 327^{*}$ \\
\hline \multicolumn{4}{|c|}{ Training monotony (AU) } \\
\hline $\mathrm{T} 1$ & $1.2 \pm 0.2$ & $1.5 \pm 0.4$ & $1.0 \pm 0.1$ \\
\hline $\mathrm{T} 2$ & $1.1 \pm 0.1$ & $1.3 \pm 0.3$ & $1.1 \pm 0.4$ \\
\hline \multicolumn{4}{|c|}{ Training strain $(A U)$} \\
\hline $\mathrm{T} 1$ & $2163 \pm 621$ & $2900 \pm 1541$ & $2037 \pm 369$ \\
\hline $\mathrm{T} 2$ & $1960 \pm 456$ & $2873 \pm 1509$ & $1584 \pm 694$ \\
\hline
\end{tabular}

was found ( $\left.\mathrm{F}=5.37, p=0.013, \eta \mathrm{p}^{2}=0.34\right)$, with post-hoc analysis demonstrating that training load was lower in the second 6 weeks for PL only $(p=0.007)$. However, no differences were reported between groups for training load, monotony and strain, indicating relative consistency in activity patterns across the intervention period.

\section{Vitamin D status}

At baseline, only 4 participants (14\%) were deemed to have 'desirable' total vitamin D levels $\left(>75 \mathrm{nmol} \cdot \mathrm{L}^{-1}\right)$, with $9(32 \%)$ and 14 (50\%) participants being categorised as either 'inadequate' or 'insufficient' levels, respectively [42]. Only 1 individual was recorded as being deficient (4\%), with total vitamin $\mathrm{D}<25 \mathrm{nmol} \cdot \mathrm{L}^{-1}$. Vitamin $\mathrm{D}$ status is shown in Figs. 1 (absolute) and 2 (normalised).

A significant interaction effect was found for total vitamin D status $\left(25(\mathrm{OH}) \mathrm{D}_{\text {TOTAL }} ; \mathrm{F}=7.31, p=0.002, \eta \mathrm{p}^{2}=\right.$ 0.38 ), with vitamin $D_{3}$ supplementation resulting in a $70 \%$ increase in the first 6 weeks $\left(46.1 \pm 5.3 \mathrm{nmol} \cdot \mathrm{L}^{-1}\right.$ to $\left.78.5 \pm 5.1 \mathrm{nmol} \cdot \mathrm{L}^{-1}, p<0.0001\right)$, and a further $12 \%$ increase to $88.0 \pm 8.6 \mathrm{nmol} \cdot \mathrm{L}^{-1}(p<0.0001)$ by week 12 . These increases were significantly different to mean values for both vitamin $\mathrm{D}_{2}$ and PL at week $6(p \leq 0.01)$, but only PL by week $12(p=0.006)$. This corresponded with an increase in mean serum $25(\mathrm{OH}) \mathrm{D}_{3}$ (interaction effect: $\left.F=16.79, p<0.0001, \eta p^{2}=0.58\right)$ for those taking vitamin $\mathrm{D}_{3}$, at week $6\left(72.3 \pm 4.5 \mathrm{nmol} \cdot \mathrm{L}^{-1}\right)$ and week 12 $\left(82.0 \pm 7.9 \mathrm{nmol} \cdot \mathrm{L}^{-1}, p=0.049\right.$ compared to week $6, p<$ 0.0001 both compared to baseline). Based on individual adherence rates, it was estimated that vitamin $D_{3}$ supplementation resulted in $\mathrm{a}+0.05 \pm 0.01 \mathrm{nmol} \cdot \mathrm{L}^{-1}$ mean increase in total vitamin D per 100 IU ingested.

The intake of mushroom-derived vitamin $\mathrm{D}_{2}$ resulted in a significant elevation in mean serum $25(\mathrm{OH}) \mathrm{D}_{2}$ (interaction effect: $\mathrm{F}=71.62, p<0.0001, \eta \mathrm{p}^{2}=0.86$ ) from $7.0 \pm 1.1 \mathrm{nmol} \cdot \mathrm{L}^{-1}$ to $28.2 \pm 2.2 \mathrm{nmol} \cdot \mathrm{L}^{-1}$ by week $6(p<$ $0.0001)$, and a further increase to $31.4 \pm 2.1 \mathrm{nmol} \cdot \mathrm{L}^{-1}$ by week 12 ( $p=0.009$ compared to week 6), representing an overall change of $+347 \%$. However, this also corresponded with a significant $42 \%$ reduction in $25(\mathrm{OH}) \mathrm{D}_{3}$ by week $6\left(50.8 \pm 9.7 \mathrm{nmol} \cdot \mathrm{L}^{-1}\right.$ to $29.6 \pm 4.9 \mathrm{nmol} \cdot \mathrm{L}^{-1}$, $p=0.001)$, with only partial recovery $(34.4 \pm 4.2$ $\mathrm{nmol} \cdot \mathrm{L}^{-1}$ ) by week 12 (albeit not significantly different compared to baseline).

As such, vitamin $\mathrm{D}_{2}$ supplementation maintained mean vitamin D status $\left(25(\mathrm{OH}) \mathrm{D}_{\text {TOTAL }}\right)$ across the first 6 weeks, with a $14 \%$ increase to $65.8 \pm 4.3 \mathrm{nmol} \cdot \mathrm{L}^{-1}$ by week 12 (which was not significantly different to vitamin $D_{3}$ ). Based on individual adherence rates, it was estimated that vitamin $D_{2}$ supplementation resulted in $\mathrm{a}+0.01 \pm 0.01$ $\mathrm{nmol} \cdot \mathrm{L}^{-1}$ mean increase in total vitamin $\mathrm{D}$ per $100 \mathrm{IU}$ ingested $\left(p=0.013\right.$ compared to vitamin $\left.\mathrm{D}_{3}\right)$. Mean vitamin D status was largely maintained with PL over the 12-weeks. However, within condition, an initial, yet non- 


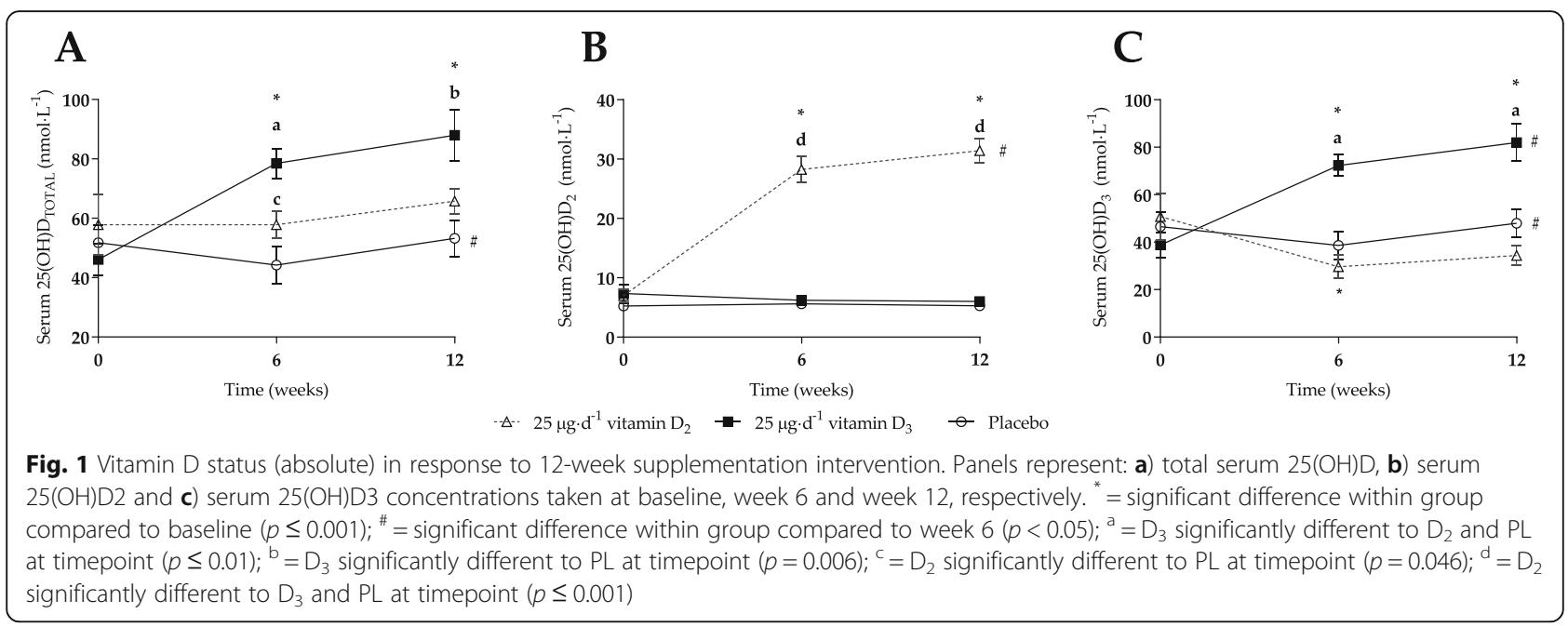

significant $15 \%$ reduction to $44.2 \pm 6.2 \mathrm{nmol} \cdot \mathrm{L}^{-1}$ occurred by week 6 , which preceded a subsequent increase to baseline values by week $12(p=0.023)$. Mean vitamin D status for PL was significantly different to both $\mathrm{D}_{2}$ and $\mathrm{D}_{3}$ groups at week $6(p \leq 0.046)$, but only the $\mathrm{D}_{3}$ group by week 12 $(p=0.006)$.

When vitamin D status was expressed as normalised relative difference (Fig. 2), there was an overall main effect reported for mean $25(\mathrm{OH}) \mathrm{D}_{\text {TOTAL }}(\mathrm{F}=6.29, p=$ 0.006). Vitamin $D_{3}$ supplementation resulted in $a+$ $1.09 \pm 0.24$ normalised increase by week 12 , compared with $+0.36 \pm 0.18$ for vitamin $\mathrm{D}_{2}(p=0.03)$ and $+0.14 \pm$ $0.10 \mathrm{nmol} \cdot \mathrm{L}^{-1}$ for PL $(p=0.01)$. This was largely accounted for by a $+1.07 \pm 0.23$ normalised increase for mean $25(\mathrm{OH}) \mathrm{D}_{3}$ (Table 5) in the first 6 weeks with vitamin $\mathrm{D}_{3}$ supplementation $(\mathrm{F}=29.32, p<0.0001)$, and a corresponding $+0.83 \pm 0.15$ normalised increase for mean $25(\mathrm{OH}) \mathrm{D}_{\text {TOTAL }}(\mathrm{F}=16.95, p<0.0001)$ compared with both vitamin $\mathrm{D}_{2}$ and PL $(p \leq 0.001)$. No significant differences were reported between conditions for normalised mean $25(\mathrm{OH}) \mathrm{D}_{3}$ (Table 5) or $25(\mathrm{OH}) \mathrm{D}_{\text {TOTAL }}$
(Fig. 2c) in the final 6 weeks of the intervention $(p>$ 0.05).

Vitamin $\mathrm{D}_{2}$ supplementation resulted in a considerable normalised increase in $25(\mathrm{OH}) \mathrm{D}_{2}(\mathrm{~F}=40.81, p<$ 0.0001 , Table 6) in the first 6-weeks $(+3.55 \pm 0.52)$, but only a small increase of $+0.13 \pm 0.05$ in the final 6 -weeks $(\mathrm{F}=5.36, p=0.012)$, with both responses being significantly different to both vitamin $\mathrm{D}_{3}$ and $\mathrm{PL}$ $(p \leq 0.03)$. The normalised change in $25(\mathrm{OH}) \mathrm{D}_{\text {TOTAL }}$ for the vitamin $\mathrm{D}_{2}$ group was consistent across both 6-week periods $(+0.15 \pm 0.12$ and $+0.16 \pm 0.05)$ (Fig. $2 b$ and c), based on a significant reduction in $25(\mathrm{OH}) \mathrm{D}_{3}$ in the first period $(-0.38 \pm 0.04, p<0.0001$ compared to vita$\min \mathrm{D}_{3}$ ), and a positive (non-significant) gain of $+0.23 \pm$ 0.08 in the second period $(p>0.05)$.

\section{Discussion}

The main finding of this study was that 12-weeks supplementation of commercially available vitamin $\mathrm{D}_{3}$ significantly increased $25(\mathrm{OH}) \mathrm{D}_{\text {TOTAL }}$ by $91 \%$ in recreationally active participants. This was largely explained by the




Table 5 Mean normalised relative difference for $25(\mathrm{OH}) \mathrm{D}_{3}$ concentrations (fold-change)

\begin{tabular}{llll}
\hline & Vitamin $\mathrm{D}_{\mathbf{2}}$ & Vitamin $\mathrm{D}_{\mathbf{3}}$ & $\mathrm{PL}$ \\
\hline$\Delta$ 0-12 weeks & $-0.22 \pm 0.09$ & $1.43 \pm 0.38^{*}$ & $0.16 \pm 0.11$ \\
$\Delta$ 0-6 weeks & $-0.38 \pm 0.04$ & $1.07 \pm 0.23^{*}$ & $-0.16 \pm 0.06$ \\
$\Delta$ 6-12 weeks & $0.23 \pm 0.08$ & $0.13 \pm 0.06$ & $0.43 \pm 0.11$
\end{tabular}

*denominates significant difference to both vitamin $\mathrm{D}_{2}$ and $\mathrm{PL}$ groups $(p \leq 0.009)$

significant 70\% increase, which occurred over the first 6week period. In contrast, non-significant increases in $25(\mathrm{OH}) \mathrm{D}_{\text {TOTAL }}$ were reported for the vitamin $\mathrm{D}_{2}(+14 \%)$ and PL groups $(+3 \%)$ across the intervention period, largely accounted for in the final 6-weeks of the study. As such, by week 6 vitamin $D_{3}$ supplementation significantly increased $25(\mathrm{OH}) \mathrm{D}_{\text {TOTAL }}$ compared to both vitamin $\mathrm{D}_{2}$ and PL. This was particularly apparent when data was normalised, with vitamin $\mathrm{D}_{3}$ demonstrating a $+83 \%$ normalised increase, compared to $+15 \%$ for vitamin $D_{2}$ and a reduction of $-14 \%$ for $\mathrm{PL}$.

By week 12 , absolute $25(\mathrm{OH}) \mathrm{D}_{\text {TOTAL }}$ were only significantly higher in the vitamin $\mathrm{D}_{3}$ group compared to PL group, but not to the vitamin $\mathrm{D}_{2}$ group. However, when normalised values were considered, the relative increase of $+109 \%$ for vitamin $D_{3}$ was significantly greater than both the $+36 \%$ and $+14 \%$ relative increases observed in the vitamin $\mathrm{D}_{2}$ and $\mathrm{PL}$ groups, respectively. These findings are in agreement with previous research highlighting the superior effectiveness of daily vitamin $\mathrm{D}_{3}$ supplementation compared to commercial vitamin $\mathrm{D}_{2}$ in improving vitamin $\mathrm{D}$ status [34-36, 40, 42, 43, 50]. Generally, vitamin $D_{2}$ has been shown to be less efficient than vitamin $D_{3}$, however, some research has suggested that vitamin $\mathrm{D}_{2}$ supplementation can be effective for maintaining or increasing vitamin D status $[21,34,35$, 42-45]. To our knowledge, there is only one study, which has shown superiority of vitamin $\mathrm{D}_{2}$ in comparison to vitamin $\mathrm{D}_{3}$ when administered daily [32].

Currently, there are a limited number of studies that have assessed the effects of vitamin $\mathrm{D}_{2}$ products derived from UV exposed mushrooms on vitamin D status, particularly in recreationally active participants or athletes. Keegan et al. (2013) suggested that mushroom-derived vitamin $\mathrm{D}_{2}$ (2000 IU daily) demonstrated similar positive effects on $25(\mathrm{OH}) \mathrm{D}_{\text {TOTAL }}$ compared to $\mathrm{D}_{3}$, but did not

Table 6 Mean normalised relative difference for $25(\mathrm{OH}) \mathrm{D}_{2}$ concentrations (fold-change)

\begin{tabular}{llll}
\hline & Vitamin $\mathrm{D}_{\mathbf{2}}$ & Vitamin $\mathrm{D}_{\mathbf{3}}$ & $\mathrm{PL}$ \\
\hline$\Delta$ 0-12 weeks & $4.24 \pm 0.69 *$ & $-0.08 \pm 0.06$ & $0.00 \pm 0.00$ \\
$\Delta$ 0-6 weeks & $3.55 \pm 0.52 *$ & $-0.07 \pm 0.04$ & $0.06 \pm 0.05$ \\
$\Delta$ 6-12 weeks & $0.13 \pm 0.05 *$ & $-0.02 \pm 0.02$ & $-0.04 \pm 0.04$
\end{tabular}

*denominates significant difference to both vitamin $D_{3}$ and $P L$ groups $(p \leq 0.03)$ include a placebo group [25]. Similarly, Urbain et al. (2011) found significant improvements in $25(\mathrm{OH}) \mathrm{D}_{\mathrm{TO}}$ TAL for both a mushroom-derived and commercial vitamin $\mathrm{D}_{2}$ supplement $(28,000$ IU weekly) compared to placebo [27]. This potentially infers that higher doses, to that employed in the current study, may be required to significantly impact vitamin $D$ status, although this has been contested elsewhere [20]. However, in this latter study [20], the processing of mushrooms may have significantly decreased vitamin $\mathrm{D}_{2}$ content, resulting in reduced daily intake. Therefore, encapsulated, dried, and pulverised extracts may increase mushroom-derived vitamin $\mathrm{D}_{2}$ bioavailability [25], with other studies indicating that daily doses $>600$ IU may be required to elicit positive changes in vitamin D status [26].

A further consideration is that of individual $25(\mathrm{OH}) \mathrm{D}_{\mathrm{TO}}$ TAL pre-intervention, and whether this limits or impacts the potential effectiveness of vitamin $\mathrm{D}_{2}$ supplementation. A recent meta-analysis [24] suggested that mushroomderived vitamin $\mathrm{D}_{2}$ could be effective in raising $25(\mathrm{OH}) \mathrm{D}$ TOтAL concentrations, but only when vitamin $\mathrm{D}$ status is classed as insufficient to deficient $\left(\leq 50 \mathrm{nmol} \cdot \mathrm{L}^{-1}\right)$. Previous research comparing mushroom-derived or commercial vitamin $\mathrm{D}_{2}$ over 6-weeks in healthy adults (mean $25(\mathrm{OH}) \mathrm{D}_{\mathrm{TOTAL}}>70 \mathrm{nmol} \cdot \mathrm{L}^{-1}$ at baseline) reported no overall treatment effects compared to control [51]. This was largely explained by increases in $25(\mathrm{OH}) \mathrm{D}_{2}$ coinciding with reductions in $25(\mathrm{OH}) \mathrm{D}_{3}$ of the same magnitude [51]. In the current study, $86 \%$ of participants were classified as having inadequate to deficient levels of $25(\mathrm{OH}) \mathrm{D}_{\text {TOTAL }}$. Baseline concentrations of $25(\mathrm{OH}) \mathrm{D}_{\text {TOTAL }}$ were statistically comparable between groups, however, the vitamin $\mathrm{D}_{2}$ group started with $57.8 \pm 10.2 \mathrm{nmol} \cdot \mathrm{L}^{-1}$ which was +11.7 $\mathrm{nmol} \cdot \mathrm{L}^{-1}$ and $+6.0 \mathrm{nmol} \cdot \mathrm{L}^{-1}$ higher than the vitamin $\mathrm{D}_{3}$ and PL group, respectively. In agreement with Cashman et al. (2016) [24], this higher starting level of $25(\mathrm{OH}) \mathrm{D}_{\text {TO- }}$ TAL could have potentially led to a non-significant interaction effect in our vitamin $\mathrm{D}_{2}$ group compared to the vitamin $\mathrm{D}_{3}$ group. It is noteworthy that $60 \%$ of the vitamin $\mathrm{D}_{2}$ group improved total vitamin $\mathrm{D}$ status from insufficient or worse (on average $38.2 \pm 3.0 \mathrm{nmol} \cdot \mathrm{L}^{-1}$ ) to inadequate $\left(62.1 \pm 4.2 \mathrm{nmol} \cdot \mathrm{L}^{-1}\right)$.

In the present study, each form of supplemented vitamin $\mathrm{D}$ had a direct and substantial positive impact on their corresponding $25(\mathrm{OH}) \mathrm{D}$ hydroxylated forms. Vitamin $\mathrm{D}_{2}$ supplementation significantly increased $25(\mathrm{OH}) \mathrm{D}_{2}$ concentration by $+347 \%$ over the 12 -week intervention. The impact of vitamin $\mathrm{D}_{3}$ supplementation on $25(\mathrm{OH}) \mathrm{D}_{3}$ followed the same trend, with an overall improvement of $+111 \%$. These results are in accordance with previous research, where $25(\mathrm{OH}) \mathrm{D}_{2}$ and $25(\mathrm{OH}) \mathrm{D}_{3}$ were measured independently [21, 30, 31, 35, $36]$, including studies using mushroom-derived vitamin $D_{2}$ $[1,25,26,51]$, demonstrating similar bioavailability of both vitamins. As both $1,25(\mathrm{OH})_{2} \mathrm{D}_{2}$ and $1,25(\mathrm{OH})_{2} \mathrm{D}_{3}$ have been 
shown to have similar biological activity in vivo [8], both forms of supplementation likely have similar metabolic effects as demonstrated elsewhere $[39,52]$. Therefore, it appears mushroom-derived vitamin $\mathrm{D}_{2}$ may offer an adjunct strategy, which is cost-effective and a more widely applicable food ingredient for populations (including vegans/vegetarians), with low vitamin D status in supporting their vitamin D intake.

Interestingly, however, in the vitamin $\mathrm{D}_{2}$ group, there was a significant $-42 \%$ reduction in $25(\mathrm{OH}) \mathrm{D}_{3}$ concentration from baseline to week 6 , followed by a nonsignificant $+16 \%$ increase to week 12 . This suppressing effect of vitamin $\mathrm{D}_{2}$ supplementation on $25(\mathrm{OH}) \mathrm{D}_{3}$ levels has been previously reported when commercially available forms of vitamin $\mathrm{D}_{2}$ were administered [34-36, $43]$, as well as mushroom-derived vitamin $\mathrm{D}_{2}[1,26,51]$. This suppressing phenomenon could be responsible for the reduced efficacy of vitamin $\mathrm{D}_{2}$ in raising $25(\mathrm{OH}) \mathrm{D}$ тотAL compared to vitamin $\mathrm{D}_{3}[4,24]$. Although suppression mechanisms are not fully understood [4], chemically, vitamin $\mathrm{D}_{2}$ and $\mathrm{D}_{3}$ are structured differently [43]. This chemical variance could lead to a different affinity for the 25-hydroxylase receptors [30].

It has also been suggested that vitamin $\mathrm{D}_{3}$ hydroxylation may be impaired by vitamin $D_{2}$ [35], as increases in $25(\mathrm{OH}) \mathrm{D}_{2}$ may lead to an increased catabolism of $25(\mathrm{OH}) \mathrm{D}_{3}$ [33]. However, this has been refuted by Stephensen et al. (2012) who argued that $25(\mathrm{OH}) \mathrm{D}_{3}$ catabolism should lead to increases in 24,25-dihydroxyvitamin $\mathrm{D}_{3}$ $\left(24,25(\mathrm{OH})_{2} \mathrm{D}_{3}\right)$, which were not detected in their study [51]. Additionally, it has been proposed that $25(\mathrm{OH}) \mathrm{D}_{3}$ has a greater binding affinity for the DBP compared to $25(\mathrm{OH}) \mathrm{D}_{2}$ in vitro [7]. A higher affinity for DBP would result in a greater concentration of circulating $25(\mathrm{OH}) \mathrm{D}_{3}$ and would decrease its rate of degradation, leading to a longer serum half-life of vitamin $\mathrm{D}_{3}$ and its metabolites [53]; and may also be associated with genotype. Indeed, depending on genotype for DBP, vitamin $\mathrm{D}_{3}$ supplementation has been shown to have differing effectiveness on raising $25(\mathrm{OH}) \mathrm{D}_{\text {TOTAL }}$ and $25(\mathrm{OH}) \mathrm{D}_{3}$ [45]. In contrast, efficacy of vitamin $D_{2}$ supplementation was not affected by DBP genotype [45]. Therefore, mushroom-derived vitamin $D_{2}$ supplementation should be less likely to be affected by DBP genotype.

In the current study, it is noteworthy that the PL group experienced a non-significant $+43 \%$ increase in $25(\mathrm{OH}) \mathrm{D}_{3}$ between week 6 to 12 (compared to $+23 \%$ and $+13 \%$ for vitamin $D_{2}$ and $D_{3}$ groups, respectively). As dietary intake of total vitamin $\mathrm{D}$ was maintained between groups across the intervention, the increases observed in $25(\mathrm{OH}) \mathrm{D}_{3}$, particularly in the vitamin $\mathrm{D}_{2}$ and PL groups, are most likely explained by a rise in the UV index (UVI), registered for Cambridgeshire, UK [54] towards the end of our intervention. Cardoso et al. (2017) reported that a higher UVI would impose a greater probability for endogenous production of vitamin $\mathrm{D}_{3}$. In their study, $25(\mathrm{OH}) \mathrm{D}_{\mathrm{TOTAL}}$ started to increase once UVI was $\geq 3$ [55]. Similar findings were reported in the current study, indicating a reduced effectiveness of vitamin $D_{2}$ supplementation when this UVI threshold has been sufficiently exceeded.

It is important to note several limitations of the current study. Although dietary total vitamin D consumption remained consistent between groups across the intervention, it was noted that due to the sparsity of recorded vitamin $\mathrm{D}_{2}$ in food items [56], the analysis software only permitted quantification of overall dietary vitamin D. Therefore, it was assumed that any alterations in $25(\mathrm{OH}) \mathrm{D}_{2}$ were due to the vitamin $\mathrm{D}_{2}$ supplementation. Physical activity levels were not significantly different between the groups at any timepoint and did not change across the 12-week intervention for the vitamin $D_{2}$ and $D_{3}$ groups, but showed a significant decrease in the PL group based on their self-reported activity diaries. Activity diaries are not as reliable as objectively measured physical activity levels [57], which may have caused an over- and/or under-reporting throughout the intervention in the PL group.

Due to unforeseen delays, the study commenced at the end of January. Whilst findings may have been different if the study had commenced earlier, i.e. November to February, our results might have been impacted by increased sunlight exposure towards the latter half of the intervention. Furthermore, whilst we analysed blood samples for $25(\mathrm{OH}) \mathrm{D}_{\mathrm{TOTAL}}, 25(\mathrm{OH}) \mathrm{D}_{2}$ and $25(\mathrm{OH}) \mathrm{D}_{3}$, it would have been beneficial to also assess calcium and parathyroid hormone levels as parameters of bone [12] and vitamin D metabolism [35]. Finally, with a larger sample size, intervention groups could have been further divided based on vitamin $\mathrm{D}$ status classification to assess the impact of vitamin $D_{2}$, with previous research suggesting that improvements may be more pertinent when participant baseline $25(\mathrm{OH}) \mathrm{D}_{\text {TOTAL }}$ levels are < $50 \mathrm{nmol} \cdot \mathrm{L}^{-1}[24,44]$. Future research should therefore consider effectiveness of mushroom-derived supplementation on vitamin D status in recreationally active individuals based on baseline levels and higher supplementation dose [58].

\section{Conclusion}

The use of a UV-radiated mushroom food ingredient was effective in maintaining $25(\mathrm{OH}) \mathrm{D}_{\text {TOTAL }}$ in healthy, recreationally active volunteers. Mushroom-derived vitamin $\mathrm{D}_{2}$ powder may offer an adjunct strategy as a more cost-effective and widely applicable food ingredient for populations, including vegans and vegetarians, with low vitamin $\mathrm{D}$ status in supporting their vitamin $\mathrm{D}$ intake. Further research is required to find optimal dosages for daily mushroom-derived vitamin $\mathrm{D}_{2}$ supplementation. 
Consistent with the literature, vitamin $\mathrm{D}_{3}$ supplementation offers significant benefits when acute elevation in vitamin D status is warranted.

\section{Abbreviations}

25(OH)D: 25-hydroxyvitamin D; 1,25(OH) 2D: active 1,25-dihydroxyvitaminD; ANOVA: analysis of variance; AU: arbitrary units; CBAL: Core Biochemical Analysis Laboratory, Addenbrookes Hospital, Cambridge; DBP: vitamin Dbinding protein; PL: Placebo; sRPE: session rating of perceived exertion

\section{Acknowledgements}

The authors wish to acknowledge support from Cambridge Commodities Ltd., UK for regulation and provision of all nutritional products and funding for analysis.

\section{Authors' contributions}

All authors were involved in the study. J.R. conceived and designed the study, with support from V.M. and J.P. following initial discussions with Cambridge Commodities Ltd. J.R., V.M., and J.P. were involved with participant organization and data collection. Data were analysed by J.R. and V.M. All authors were involved with construction of the initial manuscript. All authors reviewed the manuscript and approved the final version prior to submission.

\section{Funding}

Funding for this project was provided by Cambridge Commodities Ltd. (CCL), UK for blood analyses and provision of all nutrition supplementation.

\section{Availability of data and materials}

The datasets used and/or analysed during the current study are available from the corresponding author on reasonable request.

\section{Ethics approval and consent to participate}

This study was conducted in accordance with the Declaration of Helsinki, and the protocol was approved by the Faculty of Science and Technology Ethics Committee, Anglia Ruskin University (FST/FREP/18773).Written informed consent was obtained from all individual participants included in the study.

\section{Consent for publication}

As part of the written informed consent procedure, all participants were duly made aware (as part of both the study briefing and information sheet) that the study results may be published. As such, consent for publication was included as part of this process.

\section{Competing interests}

The authors declare that they have no competing interests.

\section{Author details}

${ }^{1}$ Cambridge Centre for Sport and Exercise Sciences, School of Psychology and Sport Science, Anglia Ruskin University, Compass House, East Road, Cambridge CB1 1PT, UK. 'Exercise and Sport Science, Nova

Southeastern-Florida University, Davie, FL, USA

Received: 15 July 2020 Accepted: 4 November 2020

Published online: 11 November 2020

\section{References}

1. Shanely RA, Nieman DC, Knab AM, Gillitt ND, Meaney MP, Jin F, et al. Influence of vitamin D mushroom powder supplementation on exerciseinduced muscle damage in vitamin D insufficient high school athletes. J Sports Sci. 2014;32(7):670-9. https://doi.org/10.1080/02640414.2013.847279.

2. Holick MF. Vitamin D deficiency. N Engl J Med. 2007;357(3):266-81. https:// doi.org/10.1056/NEJMra070553.

3. Holick MF, Binkley NC, Bischoff-Ferrari HA, Gordon CM, Hanley DA, Heaney $\mathrm{RP}$, et al. Evaluation, treatment, and prevention of vitamin D deficiency: an Endocrine Society clinical practice guideline. J Clin Endocrinol Metab. 2011; 96(7):1911-30. https://doi.org/10.1210/jc.2011-0385.

4. Wilson LR, Tripkovic L, Hart KH, Lanham-New SA. Vitamin D deficiency as public health issue: using vitamin D 2 or vitamin D 3 in future fortification strategies. Proc Nutr Soc. 2017;76(3):392-9. https://doi.org/10.1017/ S0029665117000349.

5. Zajac I, Cavuoto P, Danthiir V, Wittert GA, Krause D, Lawson L, et al. Study protocol: a randomised, double blinded, placebo-controlled clinical trial testing the effects of a vitamin D-enriched mushroom supplement on cognitive performance and mood in healthy elderly adults. Healthy Aging Res. 2016;5:1-14. https://doi.org/10.1097/01.HXR.0000511866.70301.d6.

6. Bikle DD. Vitamin D metabolism, mechanism of action, and clinical applications. Chem Biol. 2014;21(3):319-29. https://doi.org/10.1016/j. chembiol.2013.12.016.

7. Hollis BW. Comparison of equilibrium and disequilibrium assay conditions for ergocalciferol, cholecalciferol and their major metabolites. J Steroid Biochem. 1984;21(1):81-6. https://doi.org/10.1016/0022-4731(84)90063-3.

8. Tsugawa N, Nakagawa K, Kawamoto Y, Tachibana Y, Hayashi T, Ozono K, et al. Biological activity profiles of 1a, 25-Dihydroxyvitamin D2, D3, D4, D7, and 24-Epi-1a, 25-dihydroxyvitamin D2. Biol Pharm Bull. 1999;22(4):371-7. https://doi.org/10.1248/bpb.22.371.

9. Angeline ME, Gee AO, Shindle M, Warren RF, Rodeo SA. The effects of vitamin D deficiency in athletes. Am J Sports Med. 2013;41(2):461-4. https:// doi.org/10.1177/0363546513475787.

10. Cardwell G, Bornman JF, James AP, Black LJ. A review of mushrooms as a potential source of dietary vitamin D. Nutrients. 2018;10(10):1498. https:// doi.org/10.3390/nu10101498.

11. Bates $B, \operatorname{Cox} L$, Nicholson S. National diet and nutrition survey results from years 5 and 6 (combined) of the rolling programme (2012/2013-2013/2014). London: Public Health England and Food Standards Agency; 2016.

12. O'Mahony L, Stepien M, Gibney MJ, Nugent AP, Brennan L. The potential role of vitamin $D$ enhanced foods in improving vitamin $D$ status. Nutrients. 2011;3(12):1023-41. https://doi.org/10.3390/nu3121023.

13. Atherton K, Berry DJ, Parsons T, Macfarlane GJ, Power C, Hypponen E. Vitamin $\mathrm{D}$ and chronic widespread pain in a white middle-aged british population: evidence from a cross-sectional population survey. Ann Rheum Dis. 2009;68:817-22. https://doi.org/10.1136/ard.2008.090456.

14. Close GL, Russell J, Cobley JN, Owens D, Wilson G, Gregson W, et al. Assessment of vitamin D concentration in non-supplemented professional athletes and healthy adults during the winter months in the UK: implications for skeletal muscle function. J Sports Sci. 2013;31(4):344-53. https://doi.org/10.1080/02640414.2012.733822.

15. Willis KS, Peterson NJ, Larson-Meyer DE. Should we be concerned about the vitamin D status of athletes? Int J Sport Nutr Exerc Metab. 2008;18(2):20424. https://doi.org/10.1123/ijsnem.18.2.204

16. Dahlquist DT, Dieter BP, Koehle MS. Plausible ergogenic effects of vitamin D on athletic performance and recovery. J Int Soc Sports Nutr. 2015;12(1):33. https://doi.org/10.1186/s12970-015-0093-8.

17. Willis KS, Smith DT, Broughton KS, Larson-Meyer DE. Vitamin D status and biomarkers of inflammation in runners. Open Access J Sports Med. 2012;3 35. https://doi.org/10.2147/OAJSM.S31022

18. Williamson C, Buttriss J. EuroFIR: food databank systems, delivering information to researchers, consumers and industry; 2007.

19. Scientific Advisory Committee on Nutrition. Vitamin D and health report. London: The Stationary Office; 2016. https://assets.publishing.service.gov.uk/ government/uploads/system/uploads/attachment_data/file/537616/SACN_ Vitamin_D and Health_report.pdf. Accessed 21 Apr 2020.

20. Mehrotra A, Calvo M, Beelman R, Levy E, Siuty J, Kalaras M, et al. Bioavailability of vitamin D 2 from enriched mushrooms in prediabetic adults: a randomized controlled trial. Eur J Clin Nutr. 2014;68(10):1154-60. https://doi.org/10.1038/ejcn.2014.157.

21. Biancuzzo RM, Young A, Bibuld D, Cai MH, Winter MR, Klein EK, et al. Fortification of orange juice with vitamin $D(2)$ or vitamin $D(3)$ is as effective as an oral supplement in maintaining vitamin D status in adults. Am J Clin Nutr. 2010;91(6):1621-6. https://doi.org/10.3945/ajcn.2009.27972.

22. Nascimento VLVd, Bermúdez VMS, Oliveira ALLd, Kleinberg MN, Ribeiro RdTM, Abreu RFAd, et al. Characterization of a hydrolyzed oil obtained from fish waste for nutraceutical application. Food Sci Technol. 2015:35(2):321-5. https://doi.org/10.1590/1678-457x.6583.

23. Taofiq O, Fernandes Â, Barros L, Barreiro MF, Ferreira IC. UV-irradiated mushrooms as a source of vitamin D2: a review. Trends Food Sci Technol. 2017:70:82-94. https://doi.org/10.1016/j.tifs.2017.10.008.

24. Cashman KD, Kiely M, Seamans KM, Urbain P. Effect of ultraviolet lightexposed mushrooms on vitamin D status: liquid chromatography-tandem mass spectrometry reanalysis of biobanked sera from a randomized 
controlled trial and a systematic review plus meta-analysis. J Nutr. 2016; 146(3):565-75. https://doi.org/10.3945/jn.115.223784.

25. Keegan R-JH LZ, Bogusz JM, Williams JE, Holick MF. Photobiology of vitamin $D$ in mushrooms and its bioavailability in humans. Dermatoendocrinol. 2013;5(1):165-76. https://doi.org/10.4161/derm.23321.

26. Stepien M, O'Mahony L, O'Sullivan A, Collier J, Fraser WD, Gibney MJ, et al. Effect of supplementation with vitamin D2-enhanced mushrooms on vitamin D status in healthy adults. J Nutr Sci. 2013;2. https://doi.org/10.1017/ jns.2013.22.

27. Urbain $P$, Singler $F$, Ihorst $G$, Biesalski $H-K$, Bertz H. Bioavailability of vitamin D 2 from UV-B-irradiated button mushrooms in healthy adults deficient in serum 25-hydroxyvitamin D: a randomized controlled trial. Eur J Clin Nutr. 2011;65(8):965-71. https://doi.org/10.1038/ejcn.2011.53.

28. Houghton LA, Vieth $R$. The case against ergocalciferol (vitamin D2) as a vitamin supplement. Am J Clin Nutr. 2006;84(4):694-7. https://doi.org/10. 1093/ajcn/84.4.694.

29. Aloia J, Dhaliwal R, Mikhail M, Shieh A, Stolberg A, Ragolia L, et al. Free 25 (OH) D and calcium absorption, PTH, and markers of bone turnover. J Clin Endocrinol Metab. 2015;100(11):4140-5. https://doi.org/10.1210/jc.2015-2548.

30. Armas $L A$, Hollis BW, Heaney RP. Vitamin D2 is much less effective than vitamin D3 in humans. J Clin Endocrinol Metab. 2004:89(11):5387-91. https://doi.org/10.1210/jc.2004-0360.

31. Glendenning P, Chew GT, Inderjeeth CA, Taranto M, Fraser WD. Calculated free and bioavailable vitamin D metabolite concentrations in vitamin Ddeficient hip fracture patients after supplementation with cholecalciferol and ergocalciferol. Bone. 2013;56(2):271-5. https://doi.org/10.1016/j.bone. 2013.06.012.

32. Hammami MM, Yusuf A. Differential effects of vitamin D2 and D3 supplements on 25-hydroxyvitamin D level are dose, sex, and time dependent: a randomized controlled trial. BMC Endocr Disord. 2017;17(1):12 https://doi.org/10.1186/s12902-017-0163-9.

33. Heaney RP, Recker RR, Grote J, Horst RL, Armas LA. Vitamin D3 is more potent than vitamin D2 in humans. J Clin Endocrinol Metab. 2011;96(3): E447-E52. https://doi.org/10.1210/jc.2010-2230

34. Itkonen ST, Skaffari E, Saaristo P, Saarnio EM, Erkkola M, Jakobsen J, et al. Effects of vitamin D2-fortified bread v. supplementation with vitamin D2 or D3 on serum 25-hydroxyvitamin D metabolites: an 8-week randomisedcontrolled trial in young adult Finnish women. Br J Nutr. 2016;115(7):1232-9. https://doi.org/10.1017/S0007114516000192.

35. Lehmann U, Hirche F, Stangl GI, Hinz K, Westphal S, Dierkes J. Bioavailability of vitamin D2 and D3 in healthy volunteers, a randomized placebocontrolled trial. J Clin Endocrinol Metab. 2013;98(11):4339-45. https://doi. org/10.1210/jc.2012-4287.

36. Logan VF, Gray AR, Peddie MC, Harper MJ, Houghton LA. Long-term vitamin D 3 supplementation is more effective than vitamin D 2 in maintaining serum 25-hydroxyvitamin D status over the winter months. Br J Nutr. 2013; 109(6):1082-8. https://doi.org/10.1017/S0007114512002851.

37. Martineau AR, Thummel KE, Wang Z, Jolliffe DA, Boucher BJ, Griffin SJ, et al. Differential effects of Oral boluses of vitamin D2 vs vitamin D3 on vitamin D metabolism: a randomized controlled trial. J Clin Endocrinol Metab. 2019; 104(12):5831-9. https://doi.org/10.1210/jc.2019-00207.

38. Oliveri B, Mastaglia SR, Brito GM, Seijo M, Keller GA, Somoza J, et al. Vitamin D3 seems more appropriate than D2 to sustain adequate levels of 25OHD: a pharmacokinetic approach. Eur J Clin Nutr. 2015;69(6):697-702. https://doi. org/10.1038/ejcn.2015.16.

39. Shieh A, Chun RF, Ma C, Witzel S, Meyer B, Rafison B, et al. Effects of highdose vitamin D2 versus D3 on Total and free 25 -Hydroxyvitamin $D$ and markers of calcium balance. J Clin Endocrinol Metab. 2016;101(8):3070-8. https://doi.org/10.1210/jc.2016-1871

40. Trang HM, Cole D, Rubin LA, Pierratos A, Siu S, Vieth R. Evidence that vitamin D3 increases serum 25-hydroxyvitamin D more efficiently than does vitamin D2. Am J Clin Nutr. 1998;68(4):854-8. https://doi.org/10.1093/ajcn/ 68.4.854.

41. Tripkovic L, Lambert H, Hart K, Smith CP, Bucca G, Penson S, et al. Comparison of vitamin D2 and vitamin D3 supplementation in raising serum 25-hydroxyvitamin D status: a systematic review and metaanalysis. Am J Clin Nutr. 2012;95(6):1357-64. https://doi.org/10.3945/ajcn. 111.031070

42. Tripkovic L, Wilson LR, Hart K, Johnsen S, de Lusignan S, Smith CP, et al. Daily supplementation with 15 mug vitamin D2 compared with vitamin D3 to increase wintertime 25 -hydroxyvitamin D status in healthy south Asian and white European women: a 12-wk randomized, placebo-controlled foodfortification trial. Am J Clin Nutr. 2017;106(2):481-90. https://doi.org/10.3945/ ajcn.116.138693.

43. Binkley N, Gemar D, Engelke J, Gangnon R, Ramamurthy R, Krueger D, et al. Evaluation of ergocalciferol or cholecalciferol dosing, 1,600 IU daily or 50,000 IU monthly in older adults. J Clin Endocrinol Metab. 2011;96(4):981-8. https://doi.org/10.1210/jc.2010-0015.

44. Holick MF, Biancuzzo RM, Chen TC, Klein EK, Young A, Bibuld D, et al. Vitamin D2 is as effective as vitamin D3 in maintaining circulating concentrations of 25-hydroxyvitamin D. J Clin Endocrinol Metab. 2008;93(3): 677-81. https://doi.org/10.1210/jc.2007-2308.

45. Nimitphong H, Saetung S, Chanprasertyotin S, Chailurkit LO, Ongphiphadhanakul B. Changes in circulating 25-hydroxyvitamin D according to vitamin D binding protein genotypes after vitamin D(3) or D(2)supplementation. Nutr J. 2013;12:39. https://doi.org/10.1186/1475-2891-12-39.

46. Taylor K. Department of Biochemistry \& Immunology - Index: ADD.BIO 34143. Addenbrooke's Hospital. Cambridge University Hospitals NHS Foundation Trust. Directorate of Pathology. 25-Hydroxy Vitamin D3 / D2 by LC-MS/MS SOP - Version: 3.1.

47. Spiro A, Buttriss J. Vitamin D: An overview of vitamin D status and intake in Europe. Nutr Bull. 2014;39(4):322-50. https://doi.org/10.1111/nbu.12108.

48. Comyns T, Flanagan EP. Applications of the session rating of perceived exertion system in professional rugby union. Strength Cond J. 2013;35(6): 78-85. https://doi.org/10.1519/SSC.0000000000000015.

49. Foster C, Florhaug JA, Franklin J, Gottschall L, Hrovatin LA, Parker S, et al. A new approach to monitoring exercise training. J Strength Cond Res. 2001;15(1):10915. https://doi.org/10.1519/1533-4287(2001)015<0109:anatme>2.0.co;2.

50. Tripkovic L, Wilson L, Lanham-New S. Vitamin D2 vs. vitamin D3: they are not one and the same. Nutr Bull. 2017;42(4):331-7. https://doi.org/10.1111/ nbu.12293.

51. Stephensen CB, Zerofsky M, Burnett DJ, Lin Y-p, Hammock BD, Hall LM, et al. Ergocalciferol from mushrooms or supplements consumed with a standard meal increases 25-hydroxyergocalciferol but decreases 25hydroxycholecalciferol in the serum of healthy adults. J Nutr. 2012;142(7): 1246-52. https://doi.org/10.3945/jin.112.159764.

52. Lotito A, Teramoto M, Cheung M, Becker K, Sukumar D. Serum parathyroid hormone responses to vitamin $\mathrm{D}$ supplementation in overweight/obese adults: a systematic review and meta-analysis of randomized clinical trials. Nutrients. 2017:9(3):241. https://doi.org/10.3390/nu9030241.

53. Jones KS, Assar S, Harnpanich D, Bouillon R, Lambrechts D, Prentice A, et al. $25(\mathrm{OH}) \mathrm{D} 2$ half-life is shorter than $25(\mathrm{OH}) \mathrm{D} 3$ half-life and is influenced by DBP concentration and genotype. J Clin Endocrinol Metab. 2014;99(9):337381. https://doi.org/10.1210/jc.2014-1714.

54. WeatherOnline. Cambridge UV Index: 05.02.2019-30.04.2019. https://www. weatheronline.co.uk/weather/maps/city. Accessed 14 June 2019.

55. Cardoso S, Santos A, Guerra RS, Sousa AS, Padrão P, Moreira P, et al. Association between serum 25-hidroxyvitamin D concentrations and ultraviolet index in Portuguese older adults: a cross-sectional study. BMC Geriatr. 2017;17(1):1-11. https://doi.org/10.1186/s12877-017-0644-8.

56. Cashman KD, Kinsella M, McNulty BA, Walton J, Gibney MJ, Flynn A, et al. Dietary vitamin $D$ 2-a potentially underestimated contributor to vitamin $D$ nutritional status of adults? Br J Nutr. 2014;112(2):193-202. https://doi.org/ 10.1017/S0007114514000725

57. Prince SA, Adamo KB, Hamel ME, Hardt J, Gorber SC, Tremblay M. A comparison of direct versus self-report measures for assessing physical activity in adults: a systematic review. Int J Behav Nutr Phys Act. 2008;5(1): 56. https://doi.org/10.1186/1479-5868-5-56.

58. Bouillon $R$, Verlinden $L$, Verstuyf $A$. Is vitamin $D 2$ really bioequivalent to vitamin D3? Endocrinol. 2016:157(9):3384-7. https://doi.org/10.1210/en.2016-1528.

\section{Publisher's Note}

Springer Nature remains neutral with regard to jurisdictional claims in published maps and institutional affiliations. 